\title{
NILAI-NILAI ISLAM DALAM BAHAN AJAR TEMATIK MAKANANKU SEHAT DAN BERGIZI: SUATU KONSEP INTEGRATIF PEMBELAJARAN DI MADRASAH IBTIDAIYAH
}

\author{
Misbahul Munir ${ }^{1}$
}

\begin{abstract}
Internalization of religious values in accordance with the circumstances and conditions that are educational environment. In environmental and historical roots, madrasah system can not be separated from the symbol of Islam as a public education forum distinctively Islamic religious.

Incorporating Islamic values in teaching materials tematic in madrassas have a very important role in giving directions the life of mankind. Islamic values derived from religious instructions as a guide in efforts to achieve a meaningful life in the context of teaching materials thematic my food healthy and nutritious value of Islam can be tangible in the sub-theme (1) Halal Food and Thayyib, (2) Avail Halal Food and Thayyib, (3) Adab Eat Messenger.
\end{abstract}

Keywords: Islamic values, thematic materials

\section{A. Pendahuluan}

Kondisi yang dihadapi masyarakat saat ini terkait dengan adanya gelombang globalisasi, sehingga menempatkan nilai pengetahuan dan teknologi diposisi tertinggi sebagai prioritas utama dalam pendidikan. Pada sisi lain terdapat degradasi secara mentalitas dan moralitas yang harus segera diselesaikan. Kondisi tersebut sehingga menuntut pendidikan bukan hanya menyiapkan intelektual tinggi dalam pengetahuan dan teknologi tetapi juga intelektual yang memiliki karakter agamis Islami. Dewasa ini yang terjadi pada sistem pendidikan masih menampakkan berbagai problematika berat dan serius. Pemecahan masalah atas berbagai masalah yang timbul bukan hanya dari keinginan subyektif hanya untuk meningkatkan mutu pendidikan, tetapi juga untuk menjawab tantangan masa depan berorientasi global dari keadaan masyarakat Islam Indonesia.

1 Mahasiswa Magister PGMI Pascasarjana UIN Maulana Malik Ibrahim Malang Jalan Ir. Soekarno. No.1. Kota Batu, Kode Pos. 65323. 
Memperhatikan tuntutan terhadap pendidikan ialah membentuk watak serta peradaban bangsa yang bermartabat dalam rangka mencerdaskan kehidupan bangsa. Sedangkan tantangan dunia pendidikan diera globalisasi perlunya keseimbangan baik secara prinsip rohani dan jasmani, teori dan praktik, intelektual dan emosional, antara ilmu agama dengan ilmu umum (Nata, 2013:84). Sehingga perlu adanya internalisasi nilai-nilai agama yang sesuai dengan situasi dan kondisi lingkungan pendidikan itu berada. Secara lingkungan dan akar sejarah, sistem madrasah tidak bisa dilepaskan dari simbol agama Islam sebagai wadah pendidikan umum yang berciri khas keagamaan Islam.

Berdasarkan kekhasan madrasah ibtidaiyah yang berbeda dengan sistem sekolah, sangat tepat apabila materi pembelajaran secara tematik di madrasah ibtidayah dikembangkan terintegrasi dengan basis nilai-nilai agama Islam. Kondisi tersebut memungkin adanya nuansa Islamisasi terhadap buku ajar yang dijadikan pedoman untuk membentuk siswa secara sikap, pengetahuan, dan keterampilan berdasarkan petunjuk agama al-Quran dan Hadis. Langkah ini didasarkan pada pertimbangan madrasah memiliki jati diri sebagai lembaga pendidikan Islam, ajaran agama Islam mengandung petunjuk berbagai fenomena dari kehidupan, bukan hanya tuntutan sikap hidup agama dapat terpenuhi, tetapi menjamin pemecahan masalah yang benar (Muhaimin: 2012, 202).

\section{B. Hakikat Nilai -Nilai Islam}

Islam sebagai sebuah lembaga agama merupakan dari kebutuhan ideal bagi pemeluknya. Agama memiliki tata nilai yang menjadi cetak biru bagi pedoman kehidupan pemeluknya, yakni sebagai perangkat serta acuan umum dan menyeluruh dalam menghadapi lingkungan untuk pemenuhan kebutuhan serta perangkat-perangkat keyakinan pendukung nilai-nilai paripurna dalam sebuah sistem keyakinan tersebut (Suparlan, 1995:187).

Secara spesifik nilai berdasarkan pandangan Brubacher merupakan aktivitas manusia-manusia yang komplek, dan memiliki batasan-batasan yang luas dan kompleks. Sedangkan dalam pandangan Young, nilai merupakan asumsi-asumsi abstrak dan sering tidak disadari mengenai hal-hal yang benar dan hal-hal yang penting. Wood juga berpendapat bahwa nilai merupakan petunjuk 
yang mengarahkan tingkah laku dan kepuasan dalam kehidupan sehari-hari (Muhaimin dan Mujib, 1993:109-110).

Nilai bersifat ideal dan abstrak tidak dapat dilihat oleh panca indera sedangkan yang dapat dilihat ialah aksi berbentuk tingkah laku dari aktualisasi nilai tersebut. Oleh karenanya Gazalba berpendapat bahwa nilai bukan persoalan benar salah, tetapi soal kehendak yang bersifat objektif dan memberikan kepuasan pada intelek (Muhaimin dan Mujib, 1993:110). Sehingga dapat disimpulkan nilai merupakan dapat sesuai yang dapat diuji bergantung pada objek yang menilai berdasarkan ketentuan berdasarkan analisis intelektual dan kesadaran.

Sedangkan makna nilai Agama menurut Gordon W. Allport pengalaman keagamaan seseorang yang dapat memberikan pengaruh pada kesehatan jiwa, kedamaian masyarakat, agama dipandang sebagai comprehensive commitment, dan driving integrating motive, yang mengatur seluruh hidup masyarakat (Allport, 1994: 25-26). Cara beragama seperti ini diharapkan mampu memberikan tampilan kedamaian dalam tatanan sosial.

Lebih secara spesifik nilai Agama dalam Islam berdasarkan pandangan Nurcholish Madjid bukanlah sekedar tindakan-tindakan ritual peribadatan seperti sholat dan membaca al-Qur'an serta membaca do'a. Nilai Islami memiliki keseluruhan tingkah laku yang terpuji dalam kehidupan sehari-hari, yang dilakukan demi memperoleh ridho Allah (Madjid, 1997:124). Dengan nilai Islami dapat dikatakan sebagai bentuk tingkah laku yang mencerminkan budi luhur atas dasar kepercayaan iman kepada Allah dan tanggung jawab hari kemudian.

Nilai Islam memiliki kaitan dengan dengan spiritual pada norma-norma yang telah diterapkan, baik yang berasal dari sumber ajaran agama, budaya masyarkat berasal dari berfikir secara ilmiah. Keterkaitan antara moral dan spiritual tersebut akan mempengaruhi keterkaitan sikapnya terhadap nilai-nilai kehidupan yang menjadi pijakan utama untuk menetapkan suatu pilihan, pengembangan perasaan dalam menentukan suatu tindakan.

Keberagamaan seseorang diwujudkan dalam berbagai sisi kehidupannya. Aktivitas beragama bukan hanya terjadi ketika seseorang melakukan perilaku ritual (beribadah), tetapi juga ketika 
melakukan aktivitas lain yang didorong oleh kekuatan supranatural. Bukan hanya berkaitan dengan aktivitas yang tampak dan dapat dilihat dengan mata, tetapi juga aktivitas yang tidak tampak dan terjadi dalam hati seseorang (Ancok, 1995:76).

Nilai Islami terbentuk dari keterkaitan antara norma-norma yang diterapkan agama akan menjadi seseorang dapat mengukur kebenaran suatu hal berdasarkan sudut pandang agama. Sebagai orientasi moral, sikap yang dibentuk budaya religius bermakna spiritual pada norma-norma ajaran agama yang akan menjadi acuan pertama ukuran moral.

\section{Sumber Nilai Islam dalam Kehidupan}

Nilai Islam merupakan pengembangan dari eksternalisasi ajaran agama Islam, Agama Islam sendiri bersumber dari al-Quran dan Hadist. Al-Quran merupakan sumber yang diwahyukan oleh Tuhan kepada perantaraan Nabi Muhammad yang diturunkan secara berangsur-angsur. Sementara Hadis biasa didefinisikan sebagai segala perbuatan, ucapan dan ketetapan yang disandarkan kepada nabi Muhammad (Hasan, 2006:15). Secara singkat jelaslah bahwa sumber dari ajaran agama Islam atau kandungan dari penghayatan terhadap agama Islam adalah al-Quran dan Hadis.

Sumber pengembangan nilai-nilai Islam yang berakar dari agama Islam dikembangkan oleh akar pikiran manusia yang memenuhi syarat untuk mengembangkannya. Dengan demikian nilai Islam merupakan pengembangan ajaran agama Islam yang bersumber dari al-Quran dan Hadis tetapi sumber pengembangannya melalui akal pikiran manusia. Oleh karena itu dalam Islam ada dua ajaran dasar fundamental dan ajaran tidak dasar (instrumental) atau bisa disebut alat untuk memahami ajaran dasar.

Secara instrumental untuk memahami ajaran agama, manusia perlu merenungkan hakikat Tuhan sebagai penciptaan alam semesta secara kontinyu dalam rangkaian aktivitas sehari-hari. Perenungan ini merupakan landasan bagi kebijaksanaan yang lahir dari kegiatan berfikir dan melakukan aksi dalam bentuk kegiatan bermanfaat (Saefuddin, 1998:200). Sebagaimana terfirmankan dalam ayat berikut ini: 
"Sesungguhnya, dalampenciptaan langit dan bumi, dan pergantian malam dan siang, terdapat tanda-tanda (kebesaran Allah) bagi orang yang berakal, (yaitu) orang-orang yang mengingat Allah sambil berdiri, duduk, atau dalam keadaan berbaring, dan mereka memikirkan tentang penciptaan langit dan bumi (seraya berkata), "Ya Tuhan kami, tidaklah Engkau menciptakan semua ini sia-sia; Mahasuci Engkau, lindungilah kami dari azab neraka." (QS. Ali'Imran: 190-191)

Perenungan manusia terhadap Tuhan merupakan rutinitas kontinyu sebagai bentuk kesalehan indiviual manusia dengan Tuhan, sedangakan terhadap lingkungan sosial bermasyarakat kebijaksaan muncul dari kegiatan berfikir dan berbuat dalam bentuk kesalehan secara sosial. Penjelasan lebih lanjut sebagaimana berikut ini menurut pandangan Burhanudin Daya (1993) setidaknya ada lima sumber nilai Islam dalam kehidupan yang relevan:

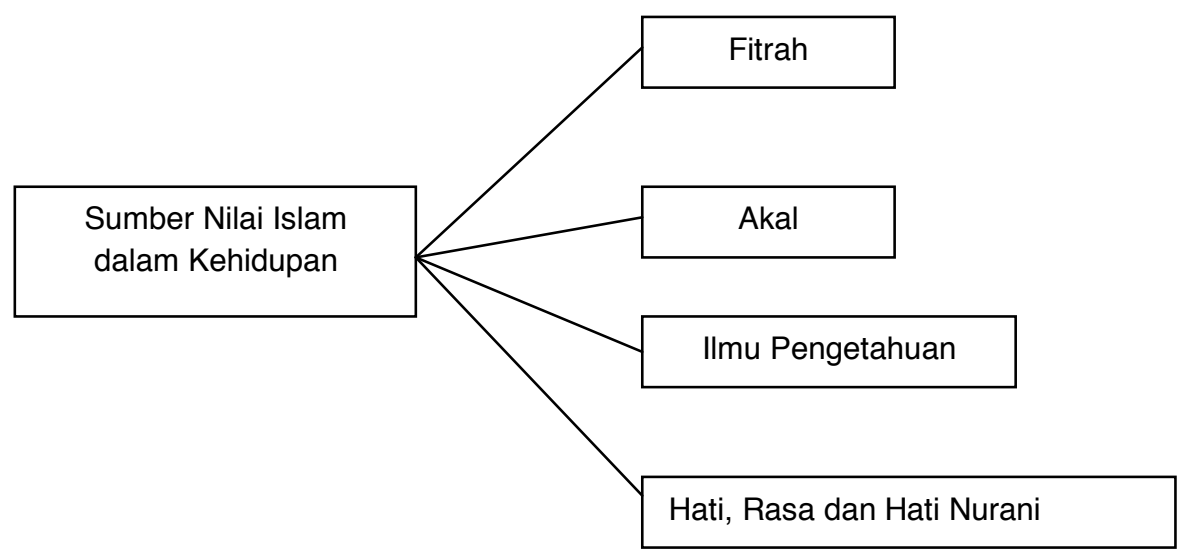

Gambar I;

Sumber Nilai Islam dalam Kehidupan

Fitrah sebagai sumber nilai Islam kehidupan, artinya nilai yang seseuai dengan kodrat manusia ciptaan Tuhan, manusi diciptakan mempunyai naluri untuk melakukan perbuat sesuai dengan fitrahnya sesuai dengan yang dititahkan Tuhan melalui perantara rasulnya, berbentuk taqwa, iman, dan keadilan. 
Akal sebagai sumber nilai Islam dalam kehidupan, al-Quran memberikan penghargaan terdap posisi akal sebagai kesempurnaan penciptaan manusia. Sebagaimana pendapat Abu Huzail mengatakan bahwa "akal merupakan daya untuk memperoleh pengetahuan, dan juga daya yang membuat seseorang dapat membedakan antara dirinya dan benda lain, dan juga antara benda yang satu dari yang lain". Lebih jauh lagi akal juga memiliki potensi untuk membedakan antara kebaikan dan kejahatan (Huzail, 1982:12).

Ilmu pengetahuan sebagai sumber nilai Islam kehidupan, anjuran untuk memperoleh ilmu pengetahuan sangat populer di dalam alQuran. Dalam Hadis juga menjelaskan agar menuntut ilmu dari ayunan sampai ke liang kubur, atau mencari ilmu sampai negeri Cina. Kenyataan ini memperkuat posisi ilmu pengetahuan dalam Islam. Untuk itu peranan penting ilmu pengetahuan tidak dapat dipisahkan dari akidah Islam (Daud, 2003:121).

Hati, rasa, dan hati nurani sebagai sumber nilai Islam dalam kehidupan, sebagimana digambarkan dalam al Quran "......Allah mempertautkan antara hati kamu, lalu menjadikan kamu", karena nikmat Allah itu, orang-orang yang bersaudara....." (Q 3:103). "...Dialah yang memperkuatkanmu dengan pertolongan-Nya dan dengan para mukmin dan yang mempersatukan hati mereka..." (Q 18:62). Penjelasan ayat tersebut memberikan perhatian begitu penting pada persolan ketenteraman hati pengikutnya. Hati merupakan simbol keberadaan Tuhan dalam diri manusia yang disebut God Spot, sebagai simbol akan segala kebajikan (Ginanjar, 2003:83).

\section{Bahan Ajar Tematik Makananku Sehat dan Bergizi}

\section{Hakekat Bahan Ajar Tematik}

Berdasarkan pendapat Abdul Majid, bahan ajar merupakan informasi, alat maupun teks yang diperlukan oleh pendidik/guru sebagai perencanaan dan penelaahan implementasi pembelajaran. Bahan ajar yang dimaksud bisa berupa bahan ajar tertulis maupun tidak tertulis (Majid, 2007:174). Bahan ajar juga bisa disebut sebagai (curriculum material), di dalamnya terdapat muatan kurikulum yang harus dipahami oleh siswa dalam proses belajar mengajar. 
Sedangkan Tomlinson berpendapat bahwa, bahan ajar adalah sesuatu yang digunakan oleh guru dan siswa untuk mempermudah penyampaian pembelajaran, meningkatkan pengalaman belajar. Bahan ajar menampilkan sosok utuh dari kompetensi yang akan dikuasai siswa dalam kegiatan pembelajaran (Tomlinson, 1998:2). Pandangan lain menurut Pannen, bahwa bahan ajar adalah materi pelajaran yang disusun secara sistematis yang digunakan guru dalam proses pembelajaran.

Berdasarkan beberapa pandangan ahli terkait bahan ajar, dapat diambil kesimpulan bahwa bahan ajar ialah seperangkat materi pembelajaran dalam bentuk informasi, media yang digunakan dalam proses pembelajaran. Secarakhususbahanajar terdiriataskomtepetensi inti sikap spiritual, sikap sosial, pengetahuan serta keterampilan yang harus dimiliki oleh siswa setalah mengikuti pembelajaran.

Pembelajaran tematik dalam pandangan HadiSubroto merupakan pembelajaran yang diawali dengan suatu pokok bahasan atau tema tertentu yang dikaitkan dengan pokok bahasan lain, konsep tertentu dikaitkan dengan konsep lain, yang dilakukan secara spontan atau direncanakan, baik dalam satu bidang studi atau lebih, dan dengan beragam pengalaman belajar siswa (Subroto dan Herawati, 2003:9). Pembelajaran tematik dapat dimaknai sebagai pembelajaran yang mengaitkan masing-masing konten materi pembelajaran dengan pengalaman lingkungan belajar siswa.

Lebih lanjut konsep pembelajaran tematik menurut Beans dalam Udin Syaefudin (2006), pembelajaran tematik diartikan sebagai pendekatan untuk mengembangkan pengetahuan siswa dalam pembentukan pengetahuan berdasarkan pada interaksi dengan lingkungan dan pengalaman hidupnya. Artinya pembelajaran tersebut tidak dilepaskan dari aktivitas yang melibatkan siswa secara langsung dalam proses informasi muatan pengetahuan. Hal ini dapat diambil kesimpulan bahwa pembelajaran tematik dapat membantu siswa untuk belajar menghubungkan apa yang telah dipelajari dan apa yang sedang dipelajari.

Sehingga bahan ajar tematik dikembangkan dan disesuaikan dengan tahapan perkembangan anak, karakteristik cara anak belajar. Sehingga Pembelajaran lebih bergairah, karena dapat berkomunikasi dalam situasi nyata. Sebagai inovasi dalam pembelajaran, sebaiknya 
model pembelajaran bagi anak usia penddikan dasar sebaiknya dilakukan dengan pembelajaran tematik. Karena muatan materi dalam pembelajaan tematik adalah menggunakan tema untuk mengaitkan beberapa mata pelajaran sehingga dapat memberikan pengalaman bermakna kepada siswa dan memudahkan siswa memperoleh informasi materi secara utuh.

\section{Karakteristik Tema Makanku Sehat dan Bergizi}

Untuk mendapatkan gambaran tentang kualifikasi kemampuan yang diharapkan serta dapat dimiliki oleh peserta didik dalam mengikuti pembelajaran Tematik dengan tema makananku sehat dan bergizi pada kelas IV, dapat dilakukan dengan mengkaji kurikulum Tematik 2013 pada peraturan Menteri Pendidikan dan Kebudayaan Nomor 67 Tahun 2013 Tentang kerangka dasar dan struktur kurikulum Sekolah Dasar/ Madrasah Ibtidaiyyah.

a. Karakteristik Tema Makananku Sehat dan Bergizi dalam buku ajar siswa kelas dirancang dengan karakteristik sebagai berikut:

1) Mengembangkankeseimbangan antara pengembangan sikap spiritual dan sosial, rasa ingin tahu, kreativitas, kerjasama dengan kemampuan intelektual dan psikomotorik

2) Sekolah merupakan bagian dari masyarakat yang memberikan pengalaman belajar terencana dimana peserta didik menerapkan apa yang dipelajari di sekolah ke masyarakat dan memanfaatkan masyarakat sebagai sumber belajar

3) Mengembangkan sikap, pengetahuan, dan keterampilan serta menerapkannya dalam berbagai situasi di sekolah dan masyarakat.

4) Memberi waktu cukup leluasa untuk mengembangkan berbagai sikap, pengetahuan, dan keterampilan

5) Kompetensi dinyatakan dalam bentuk kompetensi inti kelas yang dirinci lebih lanjut dalam kompetensi dasar matapelajaran

6) Kompetensi inti kelas menjadi unsur pengorganisasi kompetensi dasar, dimana semua kompetensi dasar dan proses pembelajaran dikembangkanuntuk mencapai kompetensi yang dinyatakan dalam kompetensi inti 
7) Kompetensi dasar dikembangkan didasarkan pada prinsip akumulatif, saling memperkuat dan memperkaya antar matapelajaran dan jenjang pendidikan.

Tabel I

\section{Standar Kompetensi Lulusan Kelas 4}

\begin{tabular}{|l|l|}
\hline \multicolumn{1}{|c|}{ DOMAIN } & \multicolumn{1}{|c|}{ SD/MI } \\
\hline SIKAP & $\begin{array}{l}\text { Memiliki perilaku yang mencerminkan sikap orang } \\
\text { beriman, berakhlak mulia, berilmu, percaya diri, dan } \\
\text { bertanggung jawab dalam berinteraksi secara efektif } \\
\text { dengan lingkungan sosial dan alam di lingkungan rumah, } \\
\text { sekolah, dan tempat bermain. }\end{array}$ \\
\hline PENGETAHUAN & $\begin{array}{l}\text { Memiliki pengetahuan faktual dan konseptual berdasarkan } \\
\text { rasa ingin tahunya tentang ilmu pengetahuan, teknologi, } \\
\text { seni, dan budaya dalam wawasan kemanusiaan, } \\
\text { kebangsaan, kenegaraan, dan peradaban terkait } \\
\text { fenomena dan kejadian di lingkungan rumah, sekolah, dan } \\
\text { tempat bermain. }\end{array}$ \\
\hline KETERAMPILAN & $\begin{array}{l}\text { Memiliki kemampuan pikir dan tindak yang produktif dan } \\
\text { kreatif dalam ranah abstrak dan konkret sesuai dengan } \\
\text { yang ditugaskan kepadanya. }\end{array}$ \\
\hline
\end{tabular}

\section{Tabel II}

\section{Uraian dari Kompetensi Inti}

\begin{tabular}{|ll|}
\hline 1) & $\begin{array}{l}\text { Menerima, menjalankan dan menghargai ajaran agama yang } \\
\text { dianutnya. }\end{array}$ \\
\hline 2$)$ & $\begin{array}{l}\text { Menunjukkan perilaku jujur, disiplin, tanggung jawab, santun, peduli, } \\
\text { dan percaya diri dalam berinteraksi dengan keluarga, teman, guru, dan } \\
\text { tetangganya. }\end{array}$ \\
\hline 3$)$ & $\begin{array}{l}\text { Memahami pengetahuan faktual dengan cara mengamati dan menanya } \\
\text { berdasarkan rasa ingin tahu tentang dirinya, makhluk ciptaan Tuhan } \\
\text { dan kegiatannya, dan benda-benda yang dijumpainya di rumah, di } \\
\text { sekolah dan tempat bermain. }\end{array}$ \\
\hline 4$)$ & $\begin{array}{l}\text { Menyajikan pengetahuan faktual dalam bahasa yang jelas, } \\
\text { sistematis dan logis, dalam karya yang estetis, dalam gerakan yang } \\
\text { mencerminkan anak sehat, dan dalam tindakan yang mencerminkan } \\
\text { perilaku anak beriman dan berakhlak mulia. }\end{array}$ \\
\hline
\end{tabular}

b. Pemetaan tujuan pembelajaran umum Tematik tema Makananku Sehat dan Bergizi, berbentuk struktur pengelompokkan sebagai berikut: 


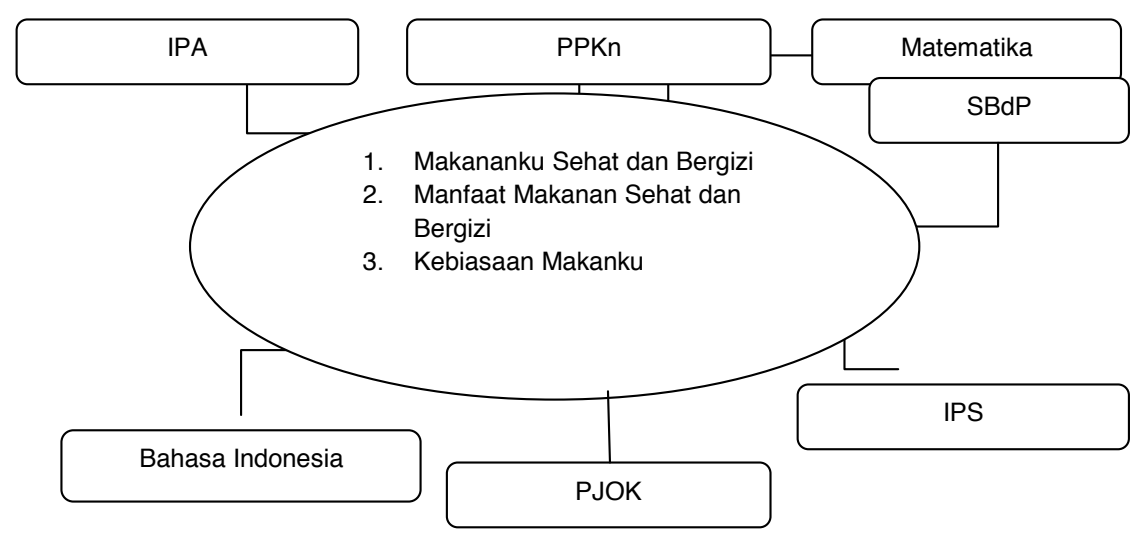

Gambar II;

Pemetaan Tema Makananku sehat dan Bergizi

\section{E. Sisipan Nilai Islam dalam Bahan Ajar Tema Makananku Sehat dan Bergizi}

Penanaman nilai Islam dalam bahan ajar di madrasah memiliki peran yang amat penting dalam memberikan arah kehidupan umat manusia. Nilai Islam yang bersumber dari petunjuk Agama menjadi pemandu dalam upaya mewujudkan suatu kehidupan yang bermakna, damai dan bermartabat. Menyadari betapa pentingnya peran agama bagi kehidupan umat manusia, maka internalisasi nilai-nilai religius dalam kehidupan setiap pribadi menjadi sebuah keniscayaan, yang ditempuh melalui pendidikan baik pendidikan di lingkungan keluarga, sekolah, maupun masyarakat.

Internalisasi nilai Islam merupakan proses menyisipkan nilainilai yang ada di dalam petunjuk Agama dalam bahan ajar. Untuk itu pengembangan bahan ajar yang terintegrasi dengan nilai Islam di lingkungan sekolah sangat penting bagi siswa. Nilai Islam akan lebih bermakna jika dikembangkan secara intensif dengan suasana lingkungan sekolah yang religius, baik pada proses belajar mengajar di dalam kelas, maupun aktivitas lainnya diluar jam belajar.

Jalaluddin Rakhmat, dalam bukunya "Islam Alternatif" menyatakan internalisasi nilai Islam dalam pendidikan yang perlu ditanamkan kepada peserta didik melalui pembacaan, pemahaman, perenungan terhadap Qur'an dan Sunnah bukan hanya fakta tetapi 
juga menghayati makna dibalik sebuah fakta (Rakhmat, 1998:117). Bukan hanya mementingkan kesalehan secara ritual tetapi juga kesalehan secara sosial, amar ma'ruf nahi munkar menjelaskan tentang halal haram berkaitan dengan aktivitas yang berhubungan dengan makanan.

Makanan merupakan pemelihara kehidupan, semua makhluk hidup yang diciptakan Tuhan baik manusia, binatang maupun tumbuhan mutlak memerlukan makanan (Mahran dan Mubasir, 2005:20). Dalam bahasa Arab yang merupakan bahasa al-Quran kata "makanan" dinyatakan dengan "Tha'am" segala sesuatu yang dimakan atau dicicipi, karena itu "minuman" pun termasuk dalam pengertian "Tha'am". Kata tha'am dalam berbagai bentuk terulang dalam al-Qur' an sebanyak 48 kali yang antara lain berbicara tentang beberapa aspek yang berkaitan dengan makanan (Shihab, 1996:137).

Sedangkan menurut Zakiah Darajat, makan menurut pengertiannya bahasa makanan diartikan sebagai aktivitas memasukkan sesuatu melalui mulut, sedangkan makanan adalah segala sesuatu yang boleh dimakan. Makanan sesuatu biasanya memiliki peran untuk memenuhi keperluan jasmani sehingga dengan demikian dapat terjaga kelangsungan hidup (Darajat, 1995:452).

Jadi makanan dapat dimaknai sebagai segala sesuatu yang di masukkan mulut dan di rasakan oleh lidah masuk kedalam tubuh untuk memenuhi keperluan jasmani sehingga dengan demikian dapat terjaga kelangsungan hidup dan beribadah kepada Tuhan. Berkaitan internalisasi nilai Islam dalam pembelajaran tematik makananku sehat dan bergizi sebagai berikut:

\section{Makanan Sehat dan Bergizi (Makanan Halal dan Thayib)}

Agama Islam menganjur umatnya untuk selalu mengkonsumsi makanan yang bukan hanya sehat, tetapi juga bergizi. Untuk itu Islam selalu mengajarkan pemeluknya untuk mengkonsumsi makanan bukan hanya halal tetapi juga thayib. Sedangkan thayib bisa dimaknai lezat, baik, sehat, menentramkan dan paling utama (Shihab, 1996:148). Dalam konteks makanan kata thayyib berarti makanan yang tidak kotor dari segi zatnya atau rusak kadaluarsa, atau bercampur benda najis. Ada juga yang mengartikan sebagai makanan yang mengundang selera bagi yang akan mengkonsumsinya dan tidak membahayakan 
fisik serta akalnya. Juga ada yang mengartikan sebagai makanan yang sehat, proporsional dan aman.

Makanan sehat adalah makanan yang mengandung gizi cukup dan seimbang di antaranya mengkonsumsi daging segar, ikan segar, dan makanan nabati. Makanan sehat bukan hanya berasal daging hewan ternak, tetapi susu hewan ternak juga menyehatkan. Makanan yang sehat juga perlu didukung oleh pola makan yang seimbang, artinya sesuai dengan kebutuhan konsumen tidak terlalu berlebihan atau berkekurangan, tidak melampaui batas yang wajar.

Makananyang sehat artinya tidak menyebabkan penyakit, dengan kata lain aman secara duniawi dan ukhrawi. Keamanan pangan (food safety) sebagimana yang dijelaskan dalam firman Alllah

"Dan makanlah makanan yang halal lagi baik dari apa yang Allah telah rizkikan kepadamu, dan bertawakallah keada Allah dan kamu beriman kepada-Nya."(QS.Al-Maidah:88)

Ayat di atas memerintahkan manusia untuk mengkonsumsi makanan dalam konteks ketakwaan pada saat menjalankan perintah konsumsi makanan. Supaya manusia berupaya untuk menghindarkan makanan yang mengakibatkan siksa dan terganggunya rasa aman. Sementara penggalan kedua dari ayat ini mengingatkan agar orangorang beriman berhati-hati dan waspada dalam memilih makanan yang hendak dikonsumsinya, dan selalu berupaya meraih karunia Allah SWT pada saat mengkonsumsinya. Ayat di atas menekankan kecuali substansi materi makanan harus halalan thayyiban juga segi kehalalan dalam mendapatkannya.

Bottom of Form

\section{Manfaat Makanan Sehat dan Bergizi (Faedah Makanan Halal dan Thayyib)}

Allah Swt telah mempersiapkan semua kebutuhan manusia sebelum menciptakannya. Allah telah menyediakan banyak makanan dan minuman untuk kelangsungan hidup seluruh manusia di bumi ini. Dari sekian banyak makanan dan minuman itu, orang yang beriman tentu akan memilih sehat serta bergizi. Untuk itu Allah memerintahkan manusia untuk memakan dan meminum yang halal dan thayib. Sedangkan orang yang mengonsumsi makanan dan minuman haram berarti dia melanggar ketentuan Allah Swt. 
Mengapa Allah menyuruh manusia memakan dan meminum yang halal Ternyata makanan dan minuman yang haram itu memiliki banyak mudharatnya. Di antaranya merupakan sumber penyakit sehingga membuat tubuh menjadi lemah. Lebih parah lagi, kita akan menjadi orang yang dibenci Allah dan Rasul-Nya. Oleh karena itu dalam Islam, selalu menganjurkan memakan dan meminum yang halal agar tubuh menjadi sehat, agar bisa lebih rajin beribadah yang nantinya mendapatkan ridho Allah Swt (Muqoddas, 2015).

Penting sekali bagi kita untuk mengetahui suatu makanan itu halal atau haram. Ini dimaksudkan agar kita tidak salah memilih yang akhirnya berdampak kurang baik bagi tubuh kita. Agama Islam merupakan agama yang sempurna. Semua hal dalam kehidupan kita sudah diatur oleh Allah Swt. termasuk halal haramnya suatu makanan dan minuman. Allah Swt. menghalalkan semua makanan dan minuman yang mengandung maslahat dan manfaat bagi manusia. Sebaliknya, Allah Swt. mengharamkan semua makanan dan minuman yang menimbulkan mudarat atau keburukan bagi manusia. Hal ini bertujuan untuk menjaga kesucian dan kebaikan hati dan akal, maupun ruh dan jasad manusia.

Manfaat makanan makanan halal dan thoyib dalam Islam bukan semata-tama tanpa sebab. Melainkan makanan yang halal dan thoyyib. Makanan yang sehat dan bergizi bukan hanya sekedar untuk menghilangkan rasa lapar, tetapi lebih utama adalah untuk mendapatkan tenaga, mendapatkan zat-zat pembangun bagi sel-sel tubuh, mempertinggi daya tahan tubuh terhadap penyakit, serta untuk menjamin kelancaran segala macam proses yang terjadi di dalam tubuh. Untuk itu, makanan yang dikonsumsi setiap hari hendaknya mengandung unsur-unsur pengasil tenaga, pembangun sel-sel, dan mengatur segala macam proses dalam tubuh. Sesuai dengan kegunaannya, maka makanan yang masuk ke dalam tubuh dapat dikelompokkan sebagai berikut :

a. Makanan sebagai sumber tenaga terutama yang mengandung hidrat arang.

b. Makanan sebagai sumber zat pembangun, digunakan sebagai pembentukan sel-sel jaringan tubuh yang baru, pembentukan sel darah merah, sel darah putih, dan zat kekebalan atau antibody. 
c. Makanan sebagai sumber zat pengatur, mutlak diperlukan walaupun sangat sedikit.

d. Makanan sebagai sumber energy dan zat pembangun tubuh merupakan elemen penting dalam tubuh manusia. Makanan akan memberikan dampak yang cukup besar terhadap ketahanan dan kondisi tubuh serta pertumbuhan tulang dan gigi (Sugiarto, 2015).

Makanan akan diproses didalam tubuh, dan diserap sari-sari makanannya untuk kemudian dibakar dan diedarkan keseluruh bagian tubuh sesuai dengan fungsinya. Makanan akan mempengaruhi perkembangan sel, jaringan serta organ pada tubuh manusia. Apabila tubuh kemasukan bahan makanan yang mengandungzat berbahaya maka tubuh akan bereaksi serta memicu kerusakan pada bagian tubuh tertentu (Hariminantyo, 2015). Oleh karena itu Islam selalu memerintahkan pemuluknya untuk memperhatikan segi kebaikan serta kandungan gizi dalam makanan, karena makanan sangat mempengaruhi perkembangan tubuh.

\section{Kebiasaan Makanku (Adab Makan menurut Rasulullah)}

Adab makan dalam Islam sesuai tuntunan Nabi MuhammadSAW merupakan teladan bagi seluruh umat Islam dalam berbagai aspek kehidupan. Keteladan baik sikap, ucapan maupun perbuatan yang telah diajarkan oleh beliau memang telah banyak diuji dan dibuktikan oleh kajian ilmiah modern tentang manfaatnya yang besar. Apabila menerapkan adab-adab makan yang beliau ajarkan. Diantara adabadab makan yang diajarkan oleh Nabi Muhammad sebagaimana yang dikutib oleh Syaikh Abdul Hamid bin Abdirrahman as-Suhaibani (2015) yang meliputi meliputi tiga hal; adab sebelum makan, adab ketika makan dan adab setelah makan sebagai berikut:

a. Adab Sebelum Makan

1) Hendaknya berusaha (memilih untuk) mendapatkan makanan dan minuman yang halal dan baik serta tidak mengandung unsur-unsur yang haram, berdasarkan firman Allah:

"Hai orang-orang yang beriman, makanlah di antara rizki yang baik-baik yang Kami berikan kepadamu..." (QS. Al-Baqarah: 172) 
2) Meniatkan tujuan dalam makan dan minum untuk menguatkan badan, agar dapat melakukan ibadah, sehingga dengan makan minumnya tersebut ia akan diberikan ganjaran oleh Allah.

3) Mencuci kedua tangannya sebelum makan, jika dalam keadaan kotor atau ketika belum yakin dengan kebersihan keduanya.

4) Meletakkan hidangan makanan pada sufrah (alas yang biasa dipakai untuk meletakkan makanan) yang digelar di atas lantai, tidak diletakkan di atas meja makan, karena hal tersebut lebih mendekatkan pada sikap tawadhu'. Hal ini sebagaimana hadits dari Anas Radhiyallahu anhu, dia berkata:

"Rasulullah Shallallahu 'alaihi wa sallam tidak pernah makan di atas meja makan dan tidak pula di atas sukurrujah." (HR. AlBukhari no. 5415)

5) Hendaknya duduk dengan tawadhu', yaitu duduk di atas kedua lututnya atau duduk di atas punggung kedua kaki atau berposisi dengan kaki kanan ditegakkan dan duduk di atas kaki kiri. Hal ini sebagaimana posisi duduk Rasulullah Shallallahu 'alaihi wa sallam yang didasari dengan sabda beliau Shallallahu 'alaihi wa sallam:

"Aku tidak pernah makan sambil bersandar, aku hanyalah seorang hamba, aku makan sebagaimana layaknya seorang hamba dan aku pun duduk sebagaimana layaknya seorang hamba."(HR. AlBukhari no. 5399)

6) Hendaknya merasa ridha dengan makanan apa saja yang telah terhidangkan dan tidak mencela-nya. A pabila berselera menyantap-nya, jika tidak suka meninggalkannya. Hal ini sebagaimana hadits dari Abu Hurairah Radhiyallahu anhu:

"Rasulullah Shallallahu 'alaihi wa sallam tidak pernah mencela makanan, apabila beliau Shallallahu 'alaihi wa sallam berselera, (menyukai makanan yang telah dihidangkan) beliau memakannya, sedangkan kalau tidak suka (tidak berselera), maka beliau meninggalkannya." (Shahih: Diriwayatkan oleh al-Bukhari (no. 3563), Muslim (no. 2064) dan Abu Dawud (no. 3764) 
Misbahul Munir - Nilai-Nilai Islam dalam Bahan ...

7) Hendaknya makan bersama-sama dengan orang lain, baik tamu, keluarga, kerabat, anak-anak atau pembantu. Sebagaimana hadits Rasulullah Shallallahu 'alaihi wa sallam:

"Berkumpullah kalian dalam menyantap makanan kalian (bersamasama), (karena) di dalam makan bersama itu akan memberikan berkah kepada kalian."(HR. Abu Dawud no. 3764)

b. Adab Ketika Sedang Makan

1) Memulai makan dengan mengucapkan,Bismillaah dan mengkahiri makan dengan pujian kepada Allah. Berdasarkan hadits Rasulullah Shallallahu 'alaihi wa sallam:

"Apabila salah seorang di antara kalian hendak makan, maka ucapkanlah: 'Bismillaah', dan jika ia lupa untuk mengucapkan bismillaah di awal makan, maka hendaklah ia mengucapkan: 'Bismillaah awwaalahu wa aakhirahu' (dengan menyebut Nama Allah di awal dan akhirnya)." (Shahih: Diriwayatkan oleh Abu Dawud (no. 3767), at-Tirmidzi (no. 1858), Ahmad (VI/143), adDarimi (no. 2026) dan an-Nasa-i dalam 'Amalul Yaum wal Lailah (no. 281). Dishahihkan oleh Syaikh al-Albani dalam Irwaa-ul Ghaliil (no. 1965))

"Barangsiapa sesudah selesai makan berdo'a: Alhamdulillaahilladzi ath'amani hadza wa razaqqaniihi min ghairi haulin minni walaa quwwatin (Segala puji bagi Allah yang telah memberi makanan ini kepadaku dan yang telah memberi rizki kepadaku tanpa daya dan kekuatanku),' niscaya akan diampuni dosanya yang telah lalu."( Shahih: Diriwayatkan oleh Abu Dawud (no. 4023), at-Tirmidzi (no. 3458), Ibnu Majah (no. 3285), Ahmad (III/439) dan al-Hakim (I/507, IV/192) serta Ibnu Sunni dalam 'Amalul Yaum wal Lailah (no. 467). Dishahihkan oleh Syaikh alAlbani dalam Irwaa-ul Ghaliil (no. 1984)

2) Hendaknya makan dengan menggunakan tiga jari tangan kanan. Menyedikitkan suapan, memperbanyak kunyahan, makan dengan apa yang terdekat darinya dan tidak memulai makan dari bagian tengah piring, berdasarkan sabda Rasulullah Shallallahu 'alaihi wa sallam: 
"Wahai anak muda, sebutlah Nama Allah (bismillaah), makanlah dengan tangan kananmu dan makanlah dari apa-apa yang dekat denganmu. Keberkahan itu turun di tengah-tengah makanan, maka makanlah dari pinggir-piring dan janganlah memulai dari bagian tengahnya.( Shahih: Diriwayatkan oleh Muslim (no. 2031 (129)), Abu Dawud (no. 3772) dan Ibnu Majah (no. 3269). Dishahihkan oleh Syaikh al-Albani rahimahullah dalam Shahiihul Jaami' (no. 379))

3) Hendaknya menjilati jari-jemarinya sebelum dicuci tangannya, sebagaimana sabda Rasulullah Shallallahu 'alaihi wa sallam:

"Apabila salah seorang di antara kalian telah selesai makan, maka janganlah ia mengusap tangannya hingga ia menjilatinya atau minta dijilatkan (kepada isterinya, anaknya)." (Shahih: Diriwayatkan oleh al-Bukhari (no. 5456) dan Muslim (no. 2031))

4) Hendaknya tidak meniup pada makanan yang masih panas dan tidak memakannya hingga menjadi lebih dingin. Tidak boleh juga, untuk meniup pada minuman yang masih panas, apabila hendak bernafas maka lakukanlah di luar gelas sebanyak tiga kali sebagaimana hadits Anas bin Malik.

"Rasulullah Shallallahu 'alaihi wa sallam jika minum, beliau bernafas (meneguknya) tiga kali (bernafas di luar gelas)."( Shahih: Diriwayatkan oleh al-Bukhari (no. 5631), Muslim (no. 2028), atTirmidzi (no. 1884), Abu Dawud (no. 3727))

5) Hendaknya menghindarkan diri dari kenyang yang melampaui batas. Hal ini berdasarkan sabda Rasulullah Shallallahu 'alaihi wa sallam:

"Tidak ada bejana yang diisi oleh manusia yang lebih buruk dari perutnya, cukuplah baginya memakan beberapa suapan sekedar dapat menegakkan tulang punggungnya (memberikan tenaga), maka jika tidak mau, maka ia dapat memenuhi perutnya dengan sepertiga makanan, sepertiga minuman dan sepertiga lagi untuk nafasnya."( Hasan: Diriwayatkan oleh Ahmad (IV/132), Ibnu Majah (no. 3349), al-Hakim (IV/121). Lihat Irwaa-ul Ghaliil (no. 1983)) 
6) Jika makan bersama orang-orang miskin, maka hendaknya mendahulukan orang miskin tersebut. Jika makan bersamasama teman-teman, diperbolehkan untuk bercanda, senda gurau, berbagi kegembiraan, suka cita dalam batas-batas yang diperbolehkan. Jika makan bersama orang yang mempunyai kedudukan, maka hendaknya ia berlaku santun dan hormat kepada mereka.

c. Adab Setelah Makan

1) Hendaknya menjilati tangannya kemudian mengusapnya atau mencuci tangannya. Dan mencuci tangan itu lebih utama dan lebih baik.

2) Memungut makanan yang jatuh ketika saat makan, sebagai bagian dari kesungguhannya dalam menerapkan adab makan dan hal itu termasuk cerminan rasa syukurnya atas limpahan nikmat yang ada.

3) Membersihkan sisa-sisa makanan yang ada di sela-sela giginya, dan berkumur untuk membersihkan mulutnya, karena dengan mulutnya itulah ia berdzikir kepada Allah Azza wa Jalla dan berbicara dengan teman-temannya.

4) Hendaknya memuji Allah Azza wa Jalla setelah selesai makan dan minum. Dan apabila meminum susu, maka ucapkanlah do'a setelah meminumnya, yaitu: "Ya Allah, berikanlah keberkahan kepada kami pada apa-apa yang telah Engkau rizkikan kepada kami dan tambahkanlah (rizki) kepada kami darinya". (Hasan: Diriwayatkan oleh Abu Dawud (no. 3730), atTirmidzi (no. 3451) dan an-Nasa-i dalam 'Amalul Yaum wal Lailah (no. 286-287). Dihasankan oleh Syaikh Nashiruddin al-Albani rahimahullah dalam Shahiih Jami'ush Shaghiir (no. 381))

\section{F. Kesimpulan}

Bahan ajar tematik merupakan inovasi dalam pembelajaran yang didasarkan pada tahapan perkembangan anak, karakteristik cara anak belajar. Sehingga Pembelajaran lebih bergairah, karena dapat berkomunikasi dalam situasi nyata. Sedangkan model pembelajaran tematik di lingkungan madrasah ibtidaiyah harus disesuaikan dengan ciri khas kelembagaan Islam yang berbeda dengan sistem pendidikan 
sekolah. Pentingnya pembelajaran tematik diberikan pada anak usia sekolah dasar, karena dalam pembelajaan tematik menggunakan tema untuk mengaitkan beberapa mata pelajaran sehingga dapat memberikan pengalaman bermakna kepada siswa dan memudahkan siswa memperoleh informasi materi secara utuh.

Memasukkan nilai Islam dalam bahan ajar temaatik di madrasah memiliki peran yang amat penting dalam memberikan arah kehidupan umat manusia. Nilai Islam yang bersumber dari petunjuk Agama menjadi pemandu dalam upaya mewujudkan suatu kehidupan yang bermakna Dalam konteks bahan ajar tematik makananku sehat dan bergizi nilai Islam bisa berwujud dalam subtema (1) Makananku Sehat dan bergizi/ Makanan Halal dan Thayyib, (2) Manfaat Makanan Sehat dan Bergizi/ Faedah Makanan Halal dan Thayyib, (3) Kebiasaan Makanku/ Adab Makan Rasulullah.

\section{Daftar Pustaka}

A.M. Saefuddin, Desekularisasi Pemikiran: Landasan Islamisasi, Bandung: Mizan, 1998.

Ancok, Djamaludin, Psikologi Islami, Solusi Islam atas Problem-problem Psikologi,Yogyakarta: Pustaka Pelajar, 1995.

Darajat, Zakiah, Ilmu Figh, Yogyakarta: Dana Bakthi Wakaf, 1995.

Tomlinson, Brian (ed). Material Development in Language Teaching. Cambridge: CUP, 1998.

Ginanjar, Ary, ESQ Power : sebuah Inner Journes Melalui al Ihsan, Jakarta: Arga, 2003.

Hasan, Aliah Purwakaniah, Psikologi Perkembangan Islam, Jakarta: Rajawali Pers, 2006.

Jalaluddin, Psikologi Agama, Jakarta: Raja Grafindo Persada, 2004.

Madjid, Nurcholish,Masyarakat Religius, Jakarta: Paramadina, 1997.

Mahran, Jamaluddin Dan Abdul Azhim Hafna Mubasir, al-Quran Bertutur Tentang Makanan dan Obat-Obatan, Yogyakarta: Mitra Pustaka, 2005.

Majid, Abdul,Perencanaan Pembelajaran: Mengembangkan Standar Kompetensi Guru. Bandung: Remaja Rosdakarya, 2007. 
Muhaimin, Pengembangan Kurikulum Pendidikan Agama Islam di Sekolah, Madrasah dan Perguruan Tinggi, Jakarta: Raja Grafindo Persada, 2012.

Muhaimin dan Abdul Mujib, Pemikiran Pendidikan Islam; Kajian Filosofis dan Kerangka Dasar Operasionalisasinya, Bandung: Trigenda Karya, 1993.

Nasution, Harun, Akal dan Wahyu Dalam Islam,Jakarta: Universitas Indonesia, 1982.

Nata, Abuddin, Kapita Selekta Pendidikan Islam; Isu-Isu Kontemporer tentang Pendidikan Islam, Jakarta: Rajawali Pers, 2013.

Rakhmat, Jalaluddin, Islam Alternatif; Ceramah-Ceramah di Kampus,Bandung: Mizan,1998.

Sa'ud, Udin Syaefuddin, Pembelajaran Tematik Terpadu, Bandung: UPI Press, 2006.

Shihab, M. Quraish ,Wawasan al-Quran, Bandung: Mizan, 1996.

Solissa, Abdul Basor dkk, Al Quran dan Pembinaan Budaya; Dialog dan Transformasi, Yogyakarta: Lembaga Studi Filsafat Islam, 1993.

Subroto,Hadi dan Ida Siti Herawati, Pembelajaran Terpadu, Jakarta: Pusat Penerbitan Universitas terbuka, 2003.

Suparlan, Parsudi, Orang Sakai di Riau: Masyarakat Terasing Dalam Masyaratkat Indonesia, (Jakarta: Yayasan Obor Indonesia, 1995.

Wan Daud, Wan Mohd Noor, Filsafat dan Praktik Pendidikan Islam; Syed M. Naquib al Attas, Jakarta: Mizan, 2003.

Rujukan Internet:

Abdul Hamid bin 'Abdirrahman as-Suhaibani, "Adab Makan dan Minum" http://almanhaj.or.id, diakses pada Tanggal 23 Maret 2015

Hariminantyo, "Makanan Sehat" http://hariminantyo.blogspot. Diakses tanggal 28Maret 2015

Icuk Sugiarto, "Pentingya Makanan Bergizi Bagi Tubuh" http:/ / icuksugiarto.blogspot.com, diakses 4 Maret 2015 